\title{
Empowerment pregnant women in preparation for lactation during the covid 19 pandemic
}

\author{
Farida Linda Sari Siregar ${ }^{*}$, Nur Afi Darti ${ }^{1}$, Evi Indriani Br. Karo ${ }^{1}$,Nurbaiti ${ }^{2}$ \\ ${ }^{1}$ Department of Maternity and Child Nursing, University Sumatra Utara \\ ${ }^{2}$ Department of Medical Surgery and Basic Nursing,University Sumatra Utara \\ Email*: farida.linda@ymail.com
}

\begin{abstract}
Empowerment of third trimester pregnant women in preparation for lactation during the COVID 19 pandemic is expected to help mothers achieve success in breastfeeding their babies after giving birth. The problem found during the pandemic was that there were restrictions on almost all routine services including maternal and neonatal health services so that pregnant women were reluctant to go to puskesmas or other health service facilities for fear of being infected and there were recommendations to postpone antenatal care and pregnancy classes. The aim of this community service is to empower pregnant women in the third trimester to prepare for lactation during the COVID-19 pandemic, to provide information support to pregnant women so that mothers are confident and confident about breastfeeding, creating a strong intention for mothers to breastfeed their babies exclusively. The service method used is health education, discussions, demonstrations and video screenings. The results of community service activities obtained by most of the knowledge of pregnant women, both about prevention efforts that pregnant women can take during the COVID 19 pandemic, how to care for breasts, how to position breastfeeding and the benefits of breastfeeding.
\end{abstract}

Key words: Empowerment, pregnant women, preparation for lactation, Covid 19.

\begin{abstract}
Abstrak
Pemberdayaan ibu hamil trimester tiga dalam persiapan laktasi di masa pandemi COVID 19 diharapkan dapat membantu ibu mencapai keberhasilan dalam menyusui bayinya setelah melahirkan. Permasalahan yang ditemukan di masa pandemic adalah adanya pembatasan hampir ke semua layanan rutin termasuk pelayanan kesehatan maternal dan neonatal sehingga ibu hamil menjadi enggan ke puskesmas atau fasiltas pelayanan kesehatan lainnya karena takut tertular dan adanya anjuran menunda pemeriksaan kehamilan dan kelas ibu hamil. Tujuan pengabdian kepada masyarakat ini adalah memberdayakan ibu hamil trimester tiga dalam melakukan persiapan laktasi dimasa pandemic COVID 19, memberikan dukungan informasi pada ibu hamil agar ibu yakin dan percaya diri untuk menyusui, menimbulkan niat yang kuat pada ibu untuk menyusui bayinya secara eksklusif. Metode pengabdian yang dilakukan adalah pendidikan kesehatan, diskusi, demostrasi dan pemutaran video. Hasil dari kegiatan pengabdian kepada masyarakat diperoleh sebagian besar pengetahuan ibu hamil baik tentang upaya pencegahan yang dapat dilakukan ibu hamil selama masa pandemic COVID 19, cara perawatan payudara, cara posisi menyusui dan manfaat ASI.
\end{abstract}

Kata kunci: Pemberdayaan, ibu hamil, persiapan laktasi, Covid 19.

\section{PENDAHULUAN}

\subsection{Latar Belakang}

Ibu hamil lebih berisiko terinfeksi virus Corona karena daya tahan tubuhnya cenderung lebih lemah. Oleh karena itu ibu hamil dianjurkan untuk tidak bepergian ke luar rumah selama pandemi COVID-19, apalagi ke rumah sakit. Prinsip-prinsip pencegahan COVID-19 pada ibu hamil, ibu nifas dan bayi baru lahir di masyarakat meliputi universal precaution dengan selalu cuci tangan memakai 
sabun selama 20 detik atau hand sanitizer, pemakaian alat pelindung diri, menjaga kondisi tubuh dengan rajin olah raga dan istirahat cukup, makan makanan yang bergizi (Kemenkes, 2020). Upaya pencegahan lain yang dapat dilakukan oleh ibu hamil, bersalin dan nifas antara lain menghindari kontak dengan orang yang sedang sakit, menutup mulut dan hidung saat batuk atau bersin dengan tissue, menggunakan masker medis, dan bila terdapat gejala COVID-19 diharapkan untuk menghubungi telepon layanan darurat yang tersedia (POGI, 2020).

Pemberian informasi ASI Eksklusif melalui media leaflet lebih berpengaruh dalam meningkatkan pengetahuan ibu tentang ASI Eksklusif. Kurangnya kesadaran atau pengetahuan ibu tentang pentingnya ASI eksklusif akan berdampak pada rendahnya motivasi ibu dalam penerapan ASI eksklusif. Peningkatan pengetahuan dapat dilakukan dengan pemberian informasi melalui media leaflet. Dukungan informasi sangat penting bagi ibu hamil dan menyusui dalam memberikan ASI eksklusif. Ibu-ibu menyusui mendapatkannya dari berbagai pihak, yaitu dari orang-orang yang berpengaruh, tenaga kesehatan, pelayanan kesehatan, serta kemudahan dan kelengkapan akses informasi ASI eksklusif (Wibowo, 2016).

Perawatan payudara sangat penting dilakukan selama masa kehamilan sampai masa menyusui. Hal ini karena payudara merupakan satu-satunya penghasil ASI yang merupakan makanan pokok bayi yang baru lahir sehingga harus dilakukan sedini mungkin. Perawatan payudara dan putting susu akan membantu melenturkan dan menguatkan putting susu sehingga memudahkan bayi untuk menyusu, serta merangsang kelenjarkelenjar payudara untuk memproduksi air susu sehingga produksi ASI banyak dan lancar. Demonstrasi perawatan payudara berpengaruh terhadap keterampilan perawatan payudara pada ibu hamil trimester ketiga di wilayah kerja Puskesmas Jeulingke, Kecamatan Syiah Kuala, Banda Aceh (Lisa, Ulfa Farrah., Putri, 2019).

Ibu-ibu di Kelurahan Tegal Sari Mandala III Kecamatan Medan Denai sebagian lebih memilih untuk memberikan bayinya susu formula menggantikan ASI karena kurangnya pengetahuan tentang pengertian ASI eksklusif, penjelasan tentang kolostrum, keunggulan ASI, manfaat pemberian ASI eksklusif, cara menyusui yang benar, cara menjaga mutu dan jumlah produksi ASI, cara bagi ibu bekerja untuk dapat memberikan ASI eksklusif, cara penyimpanan dan pemberian ASI yang disimpan di rumah. Laktasi atau menyusui merupakan suatu proses alamiah, namun sering ibu-ibu tidak berhasil menyusui atau menghentikan menyusui lebih dini. Oleh karena itu ibu-ibu memerlukan bantuan agar proses menyusui lebih berhasil.

\subsection{Permasalahan Mitra}

Berdasarkan analisa situasi diatas, permasalahnnya yang dihadapi ibu-ibu hamil dan ibu- ibu menyusui adalah sebagai berikut:

1. Ibu-ibu tidak melakukan persiapan laktasi pada masa kehamilan trimester III karena dalam situasi pandemi COVID-19 ini, banyak pembatasan hampir ke semua layanan rutin termasuk pelayanan kesehatan maternal dan neonatal sehingga ibu hamil menjadi enggan ke puskesmas atau fasiltas pelayanan kesehatan lainnya karena takut tertular.

2. Rendahnya pengetahuan ibu dan keluarga mengenai manfaat pemberian ASI eksklusif, cara perawatan payudara, cara menyusui yang benar.

\section{METODE PELAKSANAAN}

Persiapan laktasi merupakan kegiatan yang dilakukan agar dapat membantu ibu mencapai keberhasilan dalam menyusui bayinya. Pendekatan untuk menyelesaikan permasalahan laktasi (menyusui) dilakukan dengan metode:

a. Melakukan persiapan alat untuk kegiatan penyuluhan

- Masker

- Sabun cuci tangan

- Hand sanitizer 
- Buku pedoman bagi ibu hamil, ibu nifas, dan bayi baru lahir selama social distancing

- Buku pedoman pemberdayaan ibu menyusui pada program ASI eksklusif

- Phantom payudara

- Boneka bayi

- Poster posisi menyusui

- Waslap

- Baby oil

b. Melakukan kegiatan pendidikan kesehatan dengan cara:

- Memberikan informasi,

- Diskusi/tanya Jawab,

- Demonstrasi

- Pemutaran video cara merawat payudara dan posisi menyusui

Materi yang disampaikan adalah:

- Upaya pencegahan Covid 19 yang dapat dilakukan oleh ibu hamil, bersalin dan nifas

- Cara perawatan payudara pada ibu hamil dan menyusui

- Definis ASI, komposisi ASI, manfaat ASI eksklusif

- Posisi menyusui

c. Melakukan evaluasi pengetahuan ibu setelah dilakukan pendidikan kesehtaan.

\section{HASIL DAN PEMBAHASAN}

Tahapan yang telah dilakukan dalam melaksanakan solusi pemecahan masalah mitra

Tahap 1. Perencanaan, kegiatan pengabdian kepada masyarakat yang telah dilakukan diawali dengan melakukan berkoordinasi dengan Lurah Kelurahan Tegal Sari Mandala III Kecamatan Medan Denai dalam mengumpulkan ibu-ibu hamil trimester III. Jumlah ibu hamil yang bersedia untuk hadir ada 13 orang.

Tahap 2. Melakukan pendidikan kesehatan. Acara dibuka oleh lurah dengan memberikan kata sambutan. Selanjutnya tim pengabdian memberikan materi pendidikan kesehatan yaitu upaya pencegahan Covid 19 yang dapat dilakukan oleh ibu hamil, bersalin dan nifas,cara perawatan payudara pada ibu hamil dan menyusui, definis ASI, komposisi ASI, manfaat ASI eksklusif, posisi menyusui. Kegiatan pengabdian diakhiri dengan melakukan foto bersama dengan ibu hamil. Kegiatan pengabdian dapat dilihat pada gambar dibawah ini.
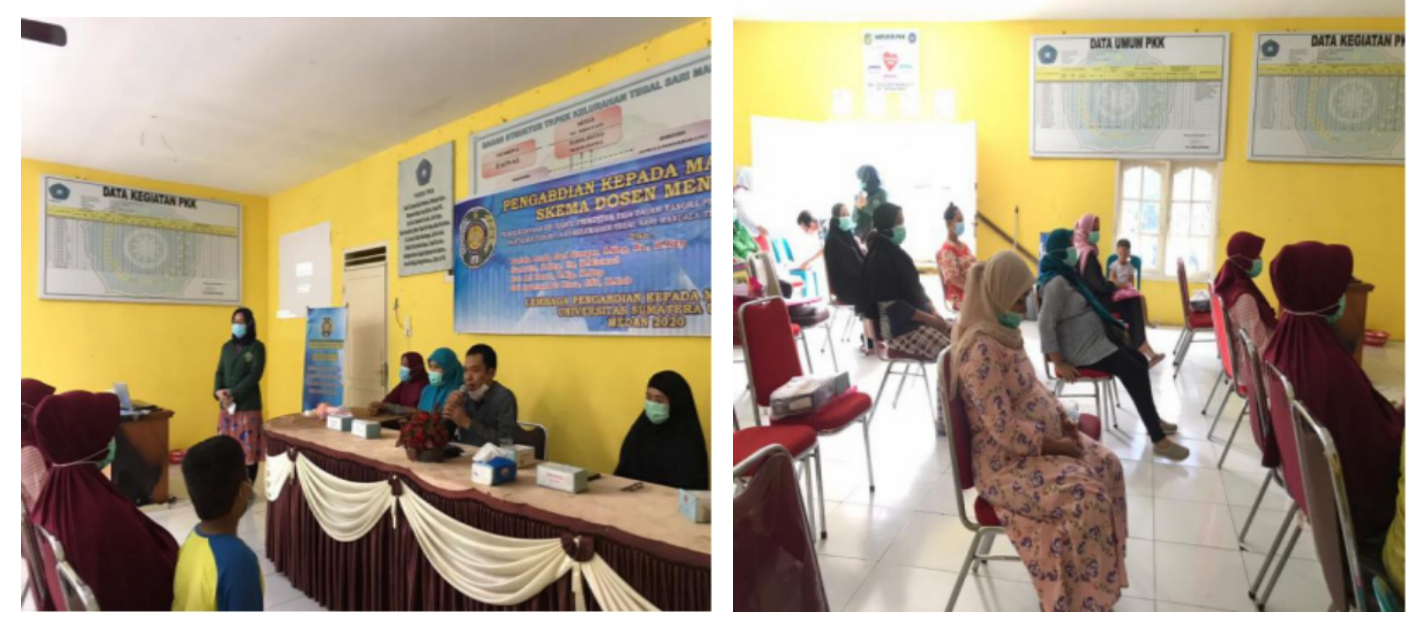

Gambar 3.1 Kegiatan kata sambuatan oleh lurah 

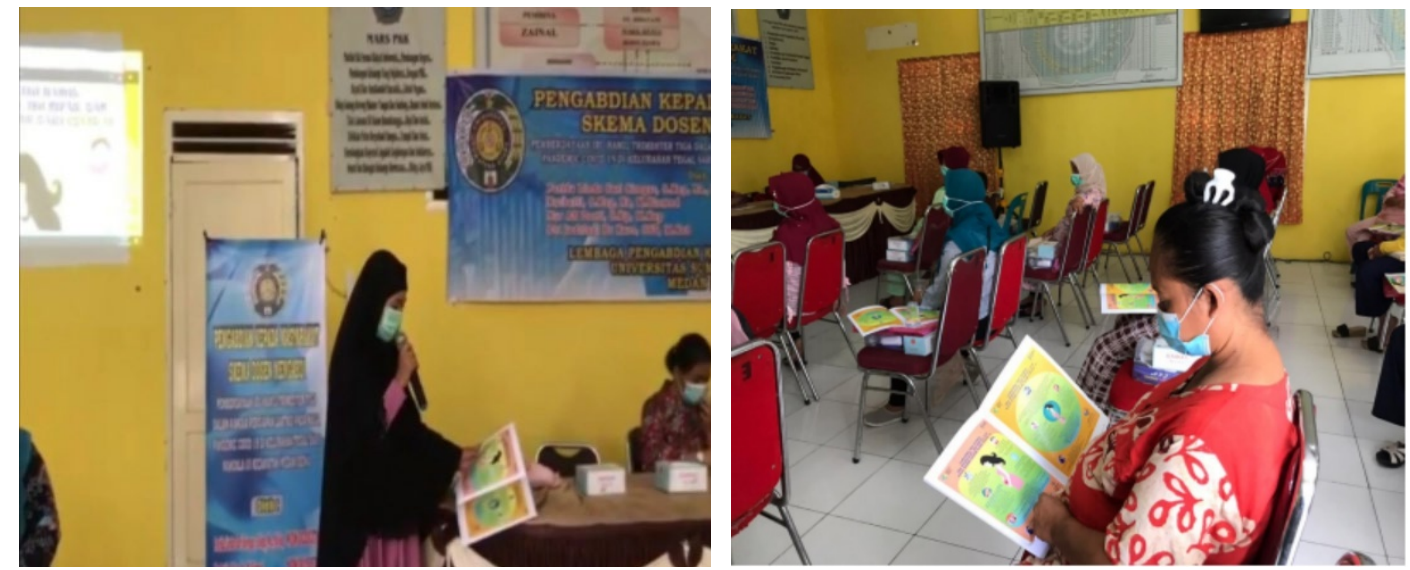

Gambar 3.2 Kegiatan penkes upaya pencegahan Covid 19 pada ibu hamil
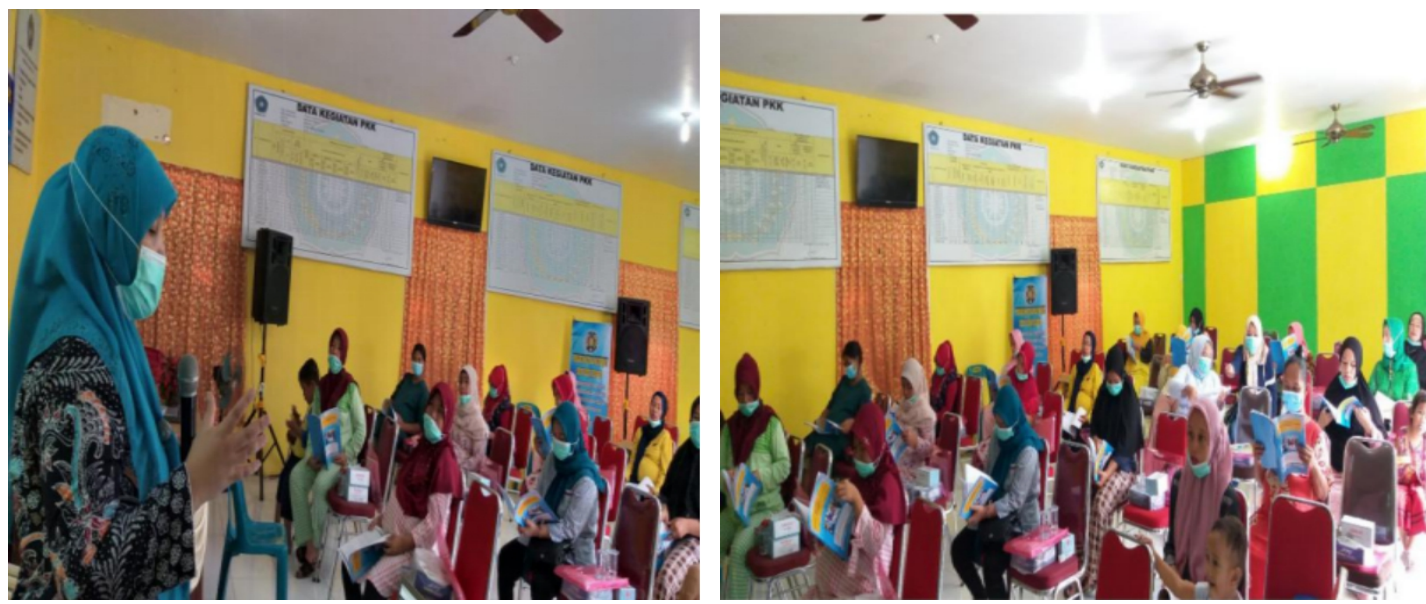

Gambar 3.3 Kegiatan penkes tentang ASI, manfaat menyusui, komposisi ASI
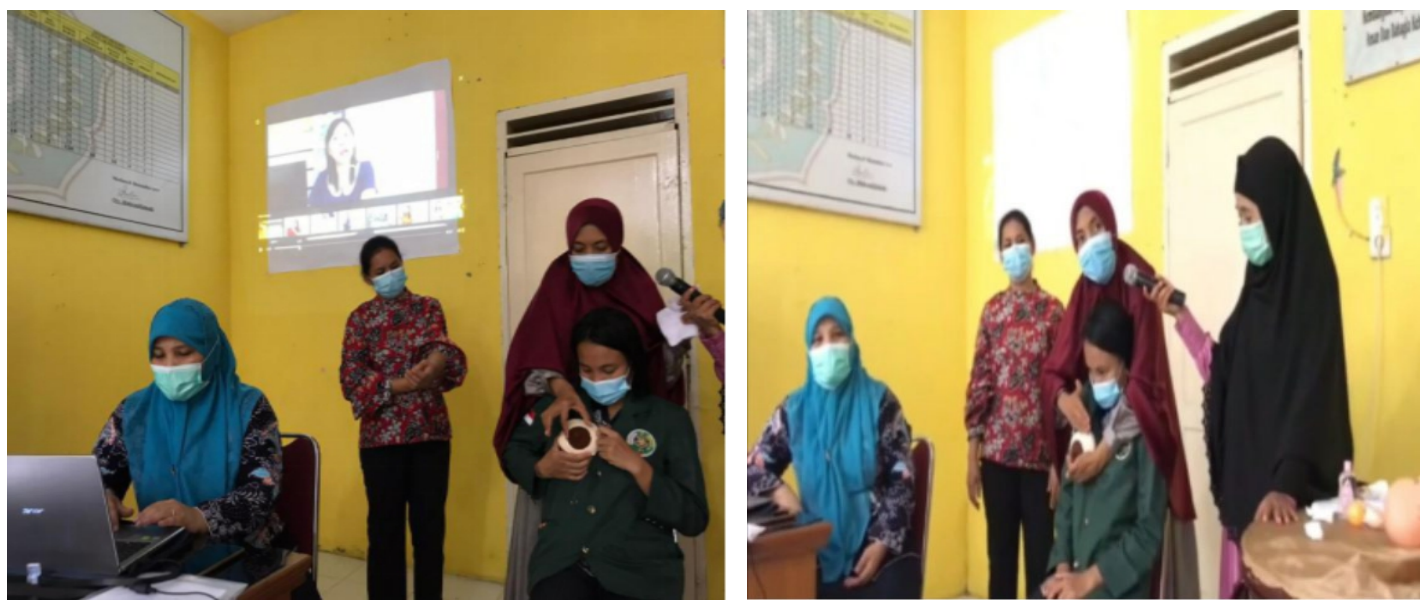

Gambar 3.4 Kegiatan demonstrasi perawatan payudara pada ibu menyusui 


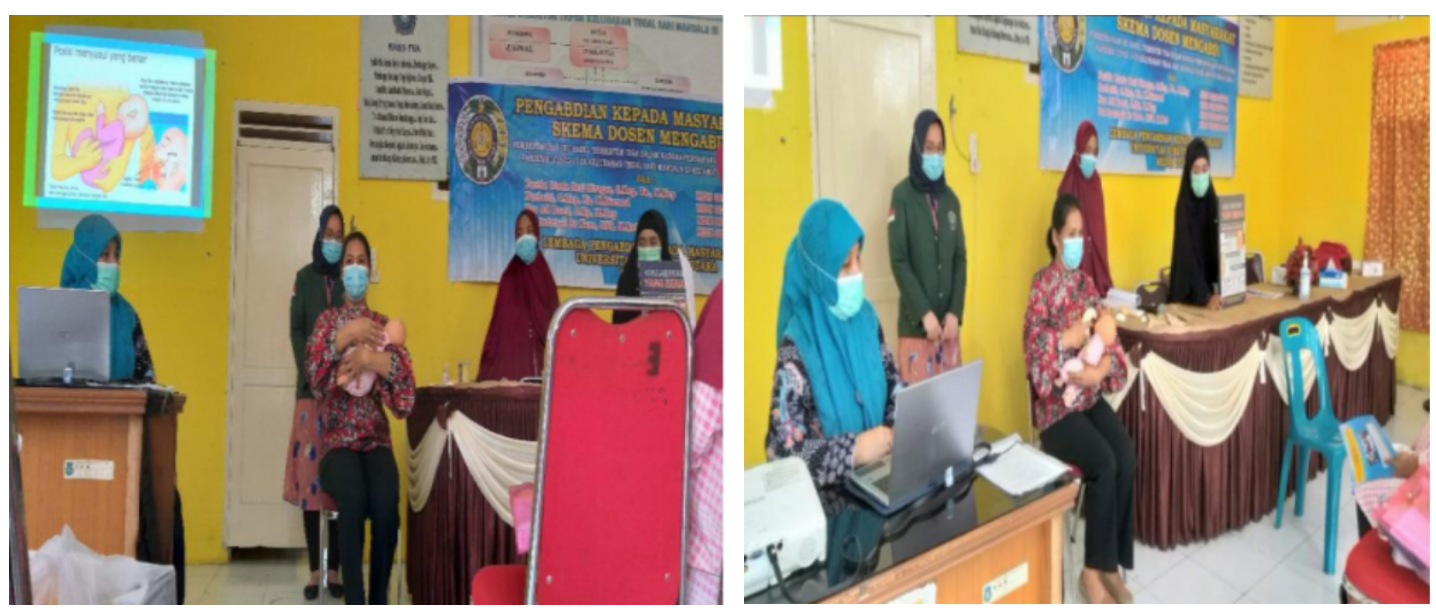

Gambar 3.5 Kegiatan demonstrasi posisi menyusui
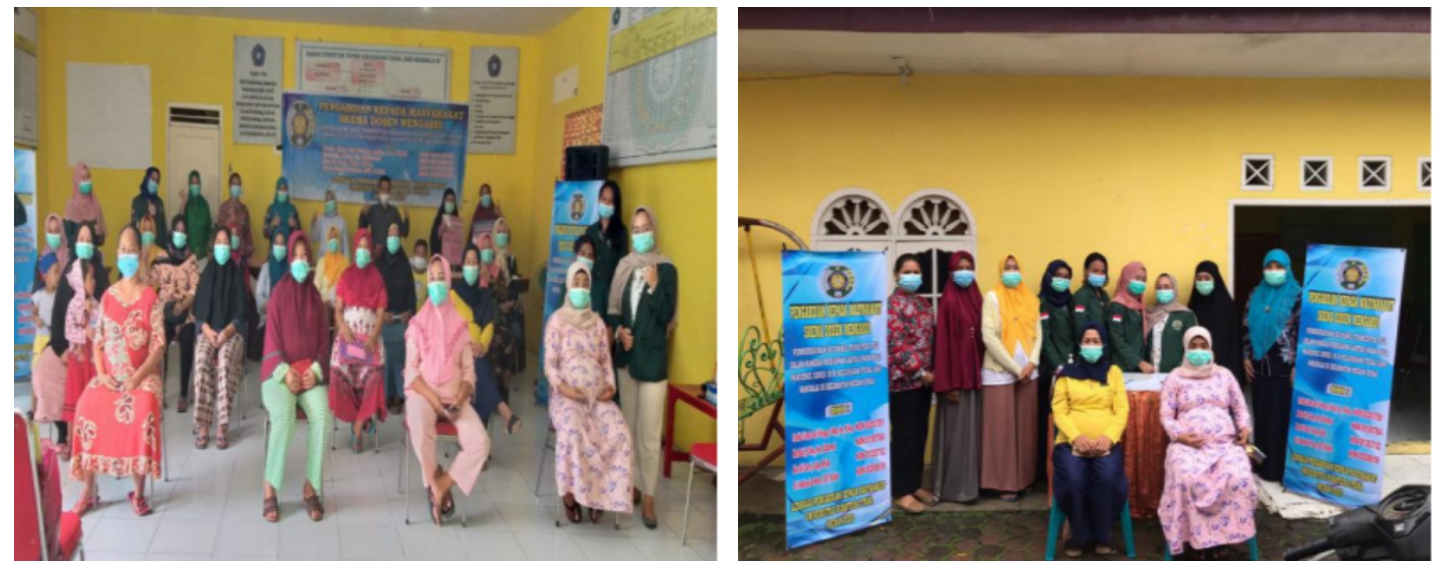

Gambar 3.6 Kegiatan foto bersama

Pengetahuan merupakan dasar untuk terbentuknya tindakan seseorang, sehingga diharapkan jika ibu mempunyai pengetahuan tentang persiapan laktasi maka ibu akan berperilaku sesuai pengetahuan yang didapatkan. Ibu hamil pada trimester tiga penting untuk mengetahui mengenai manfaat pemberian ASI eksklusif, cara menyusui yang benar, perawatan payudara pada masa hamil, dan kesiapan ibu dalam melakukan inisiasi menyusu dini (IMD). Menyusui membantu membangun hubungan yang nyaman dan penuh kasih antara ibu dan bayinya, dan melindungi bayi dari diare dan infeksi saluran pernafasan akut yang merupakan dua penyebab utama kematian bayi (Mufdillah, Subijanto, Sutisna, \& Akhyar, 2017).

\section{KESIMPULAN}

Kegiatan pemberdayaan ibu hamil trimester tiga dalam rangka persiapan laktasi pada masa pandemic Covid 19 di Kelurahan Tegal Sari Mandala III Kecamatan Medan Denai dapat meningkatkan pengetahuan ibu hamil tentang upaya pencegahan Covid 19 yang dapat dilakukan oleh ibu hamil, bersalin dan nifas, cara perawatan payudara pada ibu hamil dan menyusui, komposisi ASI, manfaat ASI eksklusif dan posisi menyusui.

\section{UCAPAN TERIMA KASIH}

Tim pelaksana kegiatan pengabdian kepada masyarakat mengucapkan terima kasih kepada Lembaga Pengabdian Kepada Masyarakat (LPPM) USU yang telah mendanai kegiatan ini melalui skim pengabdian dosen mengabdi dengan sumber dana Non PNBP Universitas Sumatera Utara 


\section{DAFTAR PUSTAKA}

Kemenkes. (2020). Selama Social Distancing. Pedoman Bagi Ibu Hamil, Ibu Nifas Dan Bayi Baru Lahir Selama Covid-19.

Lisa, Ulfa Farrah., Putri, M. (2019). Pengaruh Demonstrasi terhadap Keterampilan Perawatan Payudara pada Ibu Hamil Trimester Ketiga di Wilayah Kerja Puskesmas Jeulingke Kecamatan Syiah Kuala Banda Aceh Tahun 2018 The Effects of Demonstration on Breast Care Skills in The Third Trimester Preg, 3(1), 40-45.

Mufdillah, Subijanto, Sutisna, E. \&, \& Akhyar, M. (2017). Buku Pedoman Pemberdayaan Ibu Menyusui pada Program ASI Ekslusif. Peduli ASI Ekslusif, 0-38.

POGI. (2020). Rekomendasi Penanganan Infeksi Virus Corona (Covid-19) Pada Maternal (Hamil, Bersalin Dan Nifas). Penanganan Infeksi Virus Corona Pada Maternal, 1(3), 9-11. Retrieved from https://pogi.or.id/publish/rekomendasi-penanganan-infeksi-virus-corona-covid-19-padamaternal/

Wibowo, M. (2016). Dukungan Informasi bagi Ibu-ibu Menyusui dalam Memberikan ASI Eksklusif di Kecamatan Gondokusuman Kota Yogyakarta. Jurnal Kesehatan Masyarakat, 11(2), 241. https://doi.org/10.15294/kemas.v11i2.3694 